\title{
Political Skepticism and Anarchist Themes in the
} American Tradition

Andrew Fiala

\section{OpenEdition}

1 Journals

Electronic version

URL: https://journals.openedition.org/ejpap/545

DOI: 10.4000/ejpap.545

ISSN: 2036-4091

Publisher

Associazione Pragma

Electronic reference

Andrew Fiala, "Political Skepticism and Anarchist Themes in the American Tradition", European Journal of Pragmatism and American Philosophy [Online], V-2 | 2013, Online since 24 December 2013,

connection on 07 December 2022. URL: http://journals.openedition.org/ejpap/545 ; DOI: https:// doi.org/10.4000/ejpap.545

This text was automatically generated on 29 September 2020 .

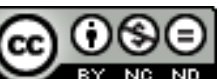

Creative Commons - Attribution-NonCommercial-NoDerivatives 4.0 International - CC BY-NC-ND 4.0 https://creativecommons.org/licenses/by-nc-nd/4.0/ 


\title{
Political Skepticism and Anarchist Themes in the American Tradition
}

\author{
Andrew Fiala
}

\section{Philosophical Anarchism in the American Tradition}

\author{
A radical pragmatist is a happy-go-lucky \\ anarchistic sort of creature. \\ William James, Pragmatism ${ }^{1}$
}

1 When William James claims that pragmatists are happy-go-lucky anarchists he points toward the skeptical, non-conformist spirit of the American philosophical tradition. This tradition includes skepticism about absolutist schemes, suspicion of authority, and a critique of institutions that might be described as a form of philosophical anarchism. Philosophical anarchism - as a philosophical theory about political reality - is not committed to a practical political agenda and it is not aimed at establishing a party or movement. Philosophical anarchism develops from a critical application of ideals of justice, maintaining that actual political systems often fail to live up to the standards of the ideal theory of political life. ${ }^{2}$ One source for skepticism toward political authority can be found in John Locke's political theory, which provided the philosophical basis for American revolutionary action against the British colonial government. But Locke and the American revolutionaries were not anarchists. They emphasized the importance of reconstituting a post-revolutionary government based on the consent of the governed. Nonetheless, Locke has been interpreted by John Simmons as pointing in the direction of what he identifies as "philosophical anarchism." Simmons explains that philosophical anarchism holds that states are illegitimate either because of a priori claims about the importance or human autonomy or because of contingent and a posteriori claims about certain features of contemporary states that shows them to fall short of the ideal theory of political life. This a posteriori approach is typical of the American anarchists and pragmatists who are not absolutist in their rejection of the state and their critique of political authority. 
2 The American tradition includes a variety of authors who can be described as philosophical anarchists, from American transcendentalists such as Thoreau and Emerson on through anarchist sentiments expressed by American pragmatists such as Jane Addams and William James. Understanding the history of this movement can help us better understand American pragmatism as a theory that is influenced by the American anarchist tradition.

\section{American Nonresistant Christian Anarchism}

In the opening salvo of his 1849 essay "Civil Disobedience," Thoreau famously throws down the gauntlet with regard to government. He says,

I heartily accept the motto, - "That government is best which governs least"; and I should like to see it acted up to more rapidly and systematically. Carried out, it finally amounts to this, which also I believe, - "That government is best which governs not at all"; and when men are prepared for it, that will be the kind of government which they will have. Government is at best but an expedient; but most governments are usually, and all governments are sometimes, inexpedient. ${ }^{4}$

Thoreau's essay concludes with a call to action-to live one's life as a counter-friction to the machine. The practical impact of this idea culminated in Thoreau's famous refusal to pay his taxes in protest against unjust government policies. Thoreau's ideas have been celebrated by anarchists who take Thoreau as a foundational author. For example, Peter Kropotkin listed Thoreau (along with Emerson) as a proponent of anarchism. ${ }^{5}$

But Thoreau's ideas were not unique. Thoreau indicates this when he affirms the motto, "that government is best which governs least." That phrase can be traced to John O'Sullivan, who took the phrase, "the best government is that which governs least," as the motto for his United States Magazine and Democratic Review - a journal that published some of Thoreau's own writings. ${ }^{6}$ Indeed, nineteenth century American life included a variety of anarchists, voluntaryists, and antinomians who were critical of government including Lysander Spooner, Ezra Heywood, and William Lloyd Garrison. Many of these early anarchists were also Christian abolitionists and pacifists who thought that the Bible pointed toward anarchism. In 1838, Garrison led a Christian Peace Party whose manifesto, "The Declaration of Sentiments" begins with the following anarchist claim, "We cannot acknowledge allegiance to any human government... Our country is the world, our countrymen are all mankind." The rationale behind this claim was that human governments and distinctions between nations were absurd and immoral and that Christian faith required cosmopolitan anarchism and pacifism.

6 For the New England anarchists, the institution of slavery was especially problematic as a sign of the injustice of the state and the need for resistance to the state or withdrawal from it. Bronson Alcott, for example, established the Fruitlands commune in Harvard, Massachusetts in the 1840's along with other members of the New England NonResistance Society. It was Alcott - not Thoreau - who first refused to pay his taxes in 1840. Alcott was jailed in 1843 in the same prison in which Thoreau was later jailed in 1846. Both Emerson and Thoreau were aware of Alcott's conscientious refusal, an act that was defended by Charles Lane in The Liberator (William Lloyd Garrison's journal of abolitionism and non-resistance). ${ }^{8}$ Lane explained that Alcott's "conscientious scruples" prevented him from "doing aught in support of a government which spends the people's money in prisons, gunpowder, halters, and the like civilized gear..." ${ }^{9}$ This indicates that 
slavery was not the only problem being protested. The general problem was the coercive instruments of state power, including military and penal power. The abolitionists had a difficult choice to make later with regard to federal military action in the American Civil War that was employed in the name of abolishing slavery. But the American anarchist Josiah Warren argued, for example, during the American Civil War: "Government, strictly and scientifically speaking is a coercive force; a man, while governed with his own consent, is not governed at all."10

7 The basic idea of the New England movement was explained by Adin Ballou, a founding member of the Non-Resistance Society, who argued that divine law was superior to human law. Ballou's non-resistant Christian pacifism led toward withdrawal from political society and toward the establishment of the Hopewood commune. Ballou's most influential work may be his 1846 book Christian Nonresistance - a book that influenced Tolstoy and which was published the same year that Thoreau refused to pay his taxes. Ballou claims that Christian pacifists may not participate in the armed services and may not serve in or offer active support to any agency or government that employs violence. He denies that this is absolute anarchism. "Let it not be said that the doctrine goes against all religion, government, social organization, constitutions, laws, order, rules, and regulations. It goes against none of these things per se. It goes for them in the highest and best sense. It goes only against such religion, government, social organization, constitutions, laws, order, rules, regulations and restraints, as are unequivocally contrary to the law of Christ." ${ }^{11}$ This indicates a form of philosophical anarchism, which is not absolutely opposed to political authority but only to unjust political authority. Ballou later explains that government per se or in itself is essentially divine. But he maintains that human government that is contrary to divine law is not justified. "Consequently all law and government absolutely contrary to the law and government of God are morally null and void." 12

8 Ballou thinks most human governments are unjust. He argues that a higher justice reduces most human government to nothing. As Ballou explains:

The conclusion is therefore unavoidable, that the will of man (human government)

- whether in one, a thousand, or many millions - has no intrinsic authority, no moral supremacy, and no rightful claim to the allegiance of man. It has no original, inherent authority whatsoever over the conscience. What then becomes of human government, as contradistinguished from the divine government? Is it not a mere cipher? When it opposes God's government, it is nothing; when it agrees with his government, it is nothing; and when it discovers a new item of duty - a new application of the general law of God - it is nothing. ${ }^{13}$

Ballou has no inherent respect for human government. But unlike Thoreau, Ballou's principle of nonresistance does not permit active resistance to human government. Instead he maintains that Christians ought to submit to and obey human government. Indeed, Ballou attempts to fend off the more radically militant and expressly anarchist implications of his ideas. He says, for example, at one point "That the worst of governments are preferable to absolute anarchy - being the least of two evils, and rendering the condition of man on the whole more tolerable." ${ }^{14}$ Thus unlike the Russian anarchists of the later half of the 19th century, Ballou walks the razor's edge between espousing outright anarchist agitation and arguing that human government is nearly always flawed. This complex standpoint helps explain Ballou's reluctance to affirm any action taken against the state or in resistance to it: such action would violate the principle of nonresistance; and it may result in the form of anarchy that Ballou is 
reluctant to affirm. Nonetheless, Ballou avers that militaristic and brutal human governments do not deserve our allegiance.

Non-resistance cannot be for war, capital punishment, slavery, and all sorts of penal injury. Nor can it be for any government that is fundamentally for these things. These things are not reconcilable with non-resistance. Its adherents cannot therefore be voluntary participators in existing governments. Not because they are opposed to government per se, but because they are utterly opposed to these fundamental evils, with which all that is good in existing governments is inseparably interwoven. ${ }^{15}$

\section{Emerson and Thoreau on Anarchy and Civil Disobedience}

There is much more to be said about Garrison, Alcott, and Ballou. However, the most influential figure in this movement is Emerson. Anarchist ideas can be found in Emerson's essay, "Politics," where Emerson writes, "Every actual State is corrupt. Good men must not obey the laws too well." ${ }^{16}$ Emerson published this essay in 1844 in his second series of Essays - the year after Alcott first refused to pay his taxes. Emerson's approach is based in a critical analysis of political institutions and a cynical evaluation of the motivations and character of political men. Emerson is skeptical about the aspirations of politicians and the justification of political structures, just as he is skeptical of established religions. In an essay from 1842, Emerson suggests that all politicians are hucksters and salesmen, peddling their wares by manipulating our opinions. "Governments, for the most part, are carried on by political merchants quite without principle, and according to the maxims of trade and huckster; so that what is true of merchants is true of public officers." ${ }^{17}$

Unlike the Christian abolitionists and anarchists mentioned above, Emerson's method is, in general, grounded in skepticism. In his essay on Montaigne, Emerson praises what he calls "wise skepticism" of the sort he associates with Montaigne and with Socrates. Emerson connects this with a critique of religion (the Church) and politics (the State). Emerson's critique of religion emphasizes moving away from ossified religious traditions, churches, and the Bible. While this spirit of skepticism and critique puts him at odds with the more Biblically based nonresistant Christian anarchism considered above, Emerson and the Christian anarchists shared similar aims with regard to the abolition of slavery and a general critique of politics and society.

Emerson claims that for most people, the justification of the state is a question. But he suggests that we are afraid to admit our skepticism. He writes, "Is not the State a question? All society is divided in opinion on the subject of the State. Nobody loves it; great numbers dislike it and suffer conscientious scruples to allegiance; and the only defence set up, is the fear of doing worse in disorganizing." ${ }^{18}$ Emerson implies that a common skepticism about political authority is held in check by the psychological disposition to accept the status quo and fear change. The state is not clearly justified. But we continue to hold our allegiance to it on pragmatic grounds: we are afraid of anything else. Emerson further explains that skepticism comes in waves and is subject to moods what Emerson explains as a philosophy of "fluxions and mobility." ${ }^{19}$ We are skeptical of the state but also skeptical of what things would be like without the state. Skepticism leaves us without comfort or rest - especially when it comes to politics, society, and the question of conformity. As Emerson concludes, "The superior mind will find itself equally 
at odds with the evils of society and with the projects that are offered to relieve them. The wise skeptic is a bad citizen." ${ }^{20}$ Emerson's transcendental individualism leaves us outside of the normal loyalties and allegiances of ordinary citizens. While Emerson is clearly not calling for the immediate destruction of social and political institutions, he registers a deep uneasiness with regard to these centralizing and domineering structures. In his essay, "Politics" Emerson explains:

Hence the less government we have the better, - the fewer laws, and the less confided power. The antidote to this abuse of formal Government is the influence of private character, the growth of the Individual; the appearance of the principal to supersede the proxy; the appearance of the wise man; of whom the existing government is, it must be owned, but a shabby imitation. ${ }^{21}$

Although Emerson does not have an explicit name for his own preferred vision of a society of self-reliant individuals, motivated by genius, imbued with character, and dedicated to friendship, the nearest names he can find are democracy and anarchy. He explains, in "Nominalist and Realist," that while democracy risks becoming anarchic, the risk is worth taking: "Democracy is morose, and runs to anarchy, but in the state, and in the schools, it is indispensable to resist the consolidation of all men into a few men."22 Emerson defers to democracy and emphasizes self-reliant individualism. This anarchist affirmation stems from his fundamental skepticism. The essay, "Nominalist and Realist" concludes with an assertion of dialectical ambivalence. The truth lies beyond our simplistic categories of thought. Emerson concludes, "How sincere and confidential we can be, saying all that lies in the mind, and yet go away feeling that all is yet unsaid, from the incapacity of the parties to know each other, although they use the same words!" ${ }^{23}$ The problem of skepticism and anarchism comes to a head here. If we adamantly maintain skepticism or militantly advocate anarchism, we end up with the thing we do not want - as when skepticism becomes a philosophical school or when anarchism becomes a political party. The problem is, in part, one of words and institutions: our words betray us when they become institutionalized. When we use words to direct our attention to the fluxional nature of reality - what Emerson calls in "Experience," the "evanescence and lubricity of all objects" - the words congeal and become solid and domineering. ${ }^{24}$ What Emerson aims at is something beyond the containment of words, parties, and institutional frameworks. In "Experience," Emerson concludes that "Life itself is a bubble and a skepticism, and a sleep within a sleep." ${ }^{25}$ This dream within the dream of the bubble of life is best observed and understood by the practice of skepticism. We doubt and question and follow our moods and experiences as they bubble and move. And its result is a kind of anarchism of the spirit and of experience. This approach culminates in the Emersonian ideal of self-reliance and nonconformity. Indeed, his essay on "Self-Reliance" can be read as a defense of a form of individualistic anarchism that is skeptical, nonconformist, and unafraid of inconsistency.

The spirit of anarchism that we find in Emerson is not necessarily active or political; it is philosophical in Simmons' sense - it is a skeptical of the status quo. But it does not lead toward active resistance to the state. It is Thoreau's further act of disobedience and taxresistance that puts Emersonian anarchism into action.

We've already noted that Thoreau's act of civil disobedience was proceeded by Alcott's tax resistance. But Thoreau's essay on the topic has had a more lasting impact - perhaps because Thoreau is a better writer and because his ideas are not as religious as those of his nonresistant Christian contemporaries. Like Ballou, Thoreau seems to believe that human government is nearly nothing. But Thoreau explains that he is not one of the "no- 
government men," by which he is most likely referring to Christian anarchists such as Ballou and Alcott. Thoreau says, "But, to speak practically and as a citizen, unlike those who call themselves no-government men, I ask for, not at once no government, but at once a better government." ${ }^{26}$ This points in the direction of subsequent development of American pragmatism - as melioristic activism and experimentation. This attitude also helps to explain why Thoreau has remained a significant figure in mainstream discussions of American political philosophy. Despite his anarchist sympathies, his withdrawal from society at Walden pond, and his anti-state civil disobedience, Thoreau is not a radical revolutionary who calls for radical destruction of the status quo (although his later support of the violent abolitionist John Brown indicates that he is not opposed to violence on principle) - as later anarchists would. Nor does he advocate complete retreat into a commune - as Christian anarchists such as Ballou did. Thoreau - at least in "Civil Disobedience" - can best be described as a skeptic. He takes some modest action on his ideas. But he is not calling for a utopian anarchist revolution based in a religiously oriented ideas about allegiance to the Kingdom of God. He does argue in "Civil Disobedience" that one should live one's life as a "counter-friction" to the machine. And Thoreau is often cited as a source for so-called "individualist anarchism" the idea that individual self-reliance stands opposed to the state. But like Emerson - and like later pragmatists - Thoreau appears to have doubts about utopian communities and religiously based anarchism. Emerson and Thoreau articulated skepticism toward government that is grounded in the ideal of self-reliant individualism - not in utopian aspiration.

\section{William James's Pragmatic Anarchism}

Another important figure in the New England movement of transcendentalists, abolitionists, pacifists, and anarchists was Henry James, Sr. - the father of the philosopher William James. Henry James Sr. was not entirely sympathetic to the individualism of Thoreau and Emerson. But like the others in this circle, James was critical of government. In a pamphlet published in 1846 - the same year Thoreau refused to pay his taxes - James explained that there was a difference between mere "government" and the moral and social spirit that unites people (what James calls somewhat confusingly "the State"). For James, "the State" is the moral spirit of a people that must be contrasted with mere government, which is a historical and political creation. For the senior James, government is merely conventional - and can be opposed on moral grounds without committing "treason" as the American revolutionaries did. Moreover, James notes that no government lives up to the standard of absolute justice. In 1846, he wrote: "Thus we find in every government, some features of its policy which necessarily have a partial bearing, which are dictated by a spirit of expediency rather than one of pure and absolute justice, by a consideration of what is due to society organized as it is, rather than what is due absolutely." ${ }^{27}$ James was also skeptical of American triumphalism - what he called "spread-eagleism" in 1861; and he thought that slavery had poisoned the American spirit. ${ }^{28}$ But he was not an advocate of the individualistic turn away from social and political institutions. Instead, he thought that there should be a reform in social and political institutions which would be directed by universal and cosmopolitan norms grounded in human rights and the Golden Rule. 

critique of large metaphysical systems. William James also links this critique to the search for a moral alternative to war, nationalism, and militarism. Pragmatists like William James were skeptical of absolutizing systems - both in metaphysics and in political life. James is particularly critical of the massiveness of modern nation-states. Mass society is not conducive to the sort of trust and familiarity that is essential for political legitimacy grounded in the consent of the governed. Mass society is a breeding ground for alienation and skepticism. The anarchist strain in American pragmatism is linked to skepticism about the justification of large social institutions, which is connected with pragmatic skepticism toward absolutizing philosophical systems. However, unlike his more militant anarchist contemporaries, James' pragmatist approach is less strident and more "philosophical." A pragmatic orientation creates a skeptical restraint on militant activism. Pragmatic meliorism is aimed at incrementally improving the world, not at radically revolutionizing it based upon some utopian ideal. Nonetheless, the direction of improvement for the American pragmatists is oriented around the critical insight into the failure of justification and the legitimation crisis that haunts the large political structures of mass society.

eneral, the common thread for Thoreau, Emerson, and William James is an emphasis on particularity, individuality, and on the meaningful experience of what James calls "small systems of things" (as James puts it in a letter from 1900). ${ }^{29}$ From this perspective, it is simple and local life that is most meaningful - not the world of states and wars. Moreover, this tradition is skeptical about the motives of politicians and doubts about the usefulness of values embodied in political formulas. This social and political skepticism holds that it is difficult to see the value in larger systems and institutions, which reify political life and give politicians increasing amounts of power. From this perspective, the state begins to lose its legitimacy.

And yet, like Thoreau, James also remained skeptical of utopian schemes. We mentioned that Emerson was also skeptical of anarchy - for Emerson there is a flux of moods and no one should tyrannize over the others, including the tyrannical desire to destroy the state and create anarchy. Not only is the violence of anarchist "direct action" immoral but the dream of utopia fades after a time. James noted this in his discussion of the Chautauqua movement in "What Makes a Life Significant." According to James, utopian communities soon become boring and we want "the element of precipitousness... of strength and strenuousness, intensity and danger." ${ }^{30}$ James appears to evoke here the spirit of Teddy Roosevelt and his praise of the strenuous life (a theme that also appears in James' essay "A Moral Equivalent of War"). But as American Imperialism spread under Roosevelt, James criticized such big heroic adventures, nationalism, militarism, and the rest of the Roosevelt agenda. ${ }^{31}$ By 1906-7 in Pragmatism, James openly declared his sympathy for anarchism. The connection between anarchism, anti-Imperialism and pragmatism is found in skepticism about the significance of absolutist and monistic philosophical and political systems.

In the essay on "What Makes Life Significant" James argued that one of the problems of life is the human tendency to want monistic answers to the question of the meaning of 
life. While anarchism poses a solution to Imperialism, the problem with anarchism, as a political party/agenda, is that is remains monistic and absolutist. James considers Tolstoy - the Christian anarchist - in some detail in this essay only to "drop him" (in James' words). And he dropped Tolstoy along with other utopian schemes because such schemes go wrong when "they pretend singly to redeem life from insignificance." ${ }^{32}$ Nonetheless, James remains sympathetic to anarchism. This sympathy makes sense against the backdrop of the development of industrial civilization and imperial politics along with its creation of "the masses," its alienating tendencies, and its militaristic nationalism. Ultimately it is not "anarchism" as a utopian political movement that attracts James. Rather - like Emerson and Thoreau - James longed for a smaller world that made sense to individuals. James put it this way in another letter (to Sarah Wyman Whitman; June 7, 1899):

I am against bigness and greatness in all their forms; and with the invisible molecular moral forces that work from individual to individual, stealing in through the crannies of the world like so many soft rootlets or like the capillary oozing of water, and yet rending the hardest monuments of man's pride, if you give them time. The bigger the unit you deal with, the hollower, the more brutal, the more mendacious is the life displayed. So I am against all big organizations as such, national ones first and foremost... ${ }^{33}$

This focus on the small personal scale of things is part of the legacy of individualism that is connected to the American transendentalist vision. Thoreau, for example, sought to find a home in a "little world" by escaping from society and returning to simple living on the shores of Walden pond. ${ }^{34}$ This longing for the small and personal is a common theme for authors who follow Thoreau. At some point, as the scale of things - technologies, economics, politics - increases, there is a qualitative shift and the personal and humane is lost amid the machinery of mass life.

In Pragmatism, James indicates that he had been reading anarchist literature and that he had great sympathy for the ideas of the anarchists. James saw in anarchism a movement that was close in spirit to his own pluralistic approach to the world. In Lecture VII of Pragmatism, James used political and social metaphors to describe the world as it appears to pragmatists. He explicitly connects his ideas with anarchism. He writes, for example, as quoted at the outset: "a radical pragmatist is a happy-go-lucky anarchistic sort of creature. ${ }^{\prime 35} \mathrm{He}$ recognized that pragmatism will be seen by rationalists and absolutists as a sort of "opportunism," since pragmatism "describes a tramp and vagrant world, adrift in space." "What James invokes with his "happy-go-lucky anarchism" is the spirit of pluralism that is open to divergent possibilities and not wedded to a monistic vision of things. This happy-go-lucky anarchism is closely related to a sort of skepticism, especially skepticism directed at big, absolutizing, and monistic systems. While not calling for direct action against the state, James is advocating for a kind of freedom that occurs through the employment of skeptical and anarchist criticism.

James also presents a general critique of centralization and what he calls in several places "bigness." Consider, for example, the statement James made in the letter to William Dean Howells that we quoted above (November 16, 1900): "I am becoming more and more an individualist and anarchist and believer in small systems of things exclusively." ${ }^{37}$ For James, big institutions and organizations are brutal, mendacious, and hollow. James points out that it is the bigness of things that alienates us and disenchants us. The primary focus of lived experience is the micro-level of individual life. That is where 
things make sense. From the individual's perspective, large metaphysical schemes appear to be as alienating as big organizations and states.

James' sympathy with anarchism is connected to his anti-Imperialism. This is clear in the essays in Pragmatism, published in 1907, when James had already been long affiliated (along with Jane Addams, Mark Twain, and John Dewey) with the Anti-Imperialist League. In Lecture VII, he makes his anti-Imperialism explicit. And in Lecture I of Pragmatism, James quotes extensively from Morrison I. Swift, a prominent anarchist author of the day, whom James describes as a "valiant anarchistic writer." ${ }^{38}$ James says, "Mr. Swift's anarchism goes a little farther than mine does, but I confess that I sympathize a good deal with... his dissatisfaction with the idealistic optimisms now in vogue." ${ }^{\prime 39}$ Morrison Swift was an anti-Imperialist - author of Imperialism and Liberty (1899) and Human Submission (1905), both of which James read. In Human Submission, which James' quoted in Pragmatism , Swift said that Americans were slavish in their submission to the rule of wealthy plutocrats; and he called for a revolution in ideas that would fend off the need for a truly violent revolution. Swift eventually would write a book in 1918 entitled Can Mankind Survive? that sounds themes that resonate with green anarchists at work today. Swift's worry is that the masses are either too stupid or too brain-washed to see that imperialism, nationalism, and militarism are leading to a dead-end for the human race. As Swift describes it in the opening salvo of his 1918 book, the Great War is opening our eyes to the chaos of civilized society and to the "utter slovenliness of man's management of the earth." ${ }^{40}$ Problems include militarism, monopoly capitalism, and big hegemonic systems. James' advocacy of pluralism and individualism should be read against the backdrop of the sorts of social and political criticism that were espoused by anarchists such as Swift.

The anarchist connections in the American pragmatist tradition run deep. Jane Addams, for example, was accused of being an anarchist. Addams travelled to Russia to meet Leo Tolstoy, the great Russian anarchist. ${ }^{41}$ She praised Tolstoy's passion for the peasants, his pacifism, and his radical change of lifestyle - i.e., the fact that he gave up his wealth and returned to a simple peasant style of life. ${ }^{42}$ She was also acquainted with several Chicago anarchists. Indeed, in 1899, the anarchist Peter Kropotkin stayed at her Hull House, during his tour of the U.S. This led some newspapers to condemn Hull House - a story that Addams details in chapter 17 of Twenty Years at Hull House. Addams, moreover, ran afoul of public opinion when some self-proclaimed "anarchists" assassinated President McKinley. As part of the backlash in response to the McKinley assassination, anarchists were rounded up and jailed in Chicago. Addams went to the mayor of Chicago to complain on their behalf. But Addams remained committed to the political process and the legal traditions of the United States. Addams held that the state ought to be dedicated to the defense of individual rights - even defending the rights of anarchists who were opposed to the state. ${ }^{43}$ Addams' point is that if the legal system is worthy of respect, then even anarchists should be extended the protection of the law. Throughout her account of her dealings with the Russian anarchists, she makes it clear that she thinks that the American system is superior - at least in principle, due to its legal orientation and its system of justice. She concludes by arguing against anarchist direct action and the idea that extralegal methods are appropriate: "When the sense of justice seeks to express itself quite outside the regular channels of established government, it has set forth on a dangerous journey inevitably ending in disaster... this is true in spite of the fact that the adventure may have been inspired by noble motives. ${ }^{{ }^{44}}$ This warning indicates the nature of the 
problem posed by skeptical criticisms of political reality. While sympathetic to anarchist critiques of the status quo, Addams was skeptical of their radical political tactics.

At about the same time that Addams was dealing with the Russian anarchists in Chicago, James was working on his lectures and book, Pragmatism. James would have agreed with Jane Addams' reluctance to support the direct action tactics of the political anarchists, even though he understood the critique of large institutions that was typical of the anarchists. For James, the problem of big mendacious institutions was not to be solved with direct action. Rather, the goal was to find a melioristic, pluralistic, and happy-golucky alternative to imperial power. It is not clear what this would look like in practice. However, one key is skeptical criticism of absolutism and imperialism in both metaphysics and political life.

\section{Conclusion}

We often forget that European thinkers were influenced by American thinkers. But the anarchist themes in the early American tradition found a receptive audience in Europe. Nietzsche quoted Emerson in order to point out that the individualistic pursuit of philosophical genius is more important than allegiance to the State. ${ }^{45} \mathrm{And}$, as mentioned at the outset, Peter Kropotkin listed Emerson and Thoreau among the anarchists in his seminal Encyclopedia article on anarchism. ${ }^{46}$ Kropotkin's own biography involves a notorious connection with Emerson. Peter Kropotkin's brother Alexander was thrown in prison in 1858 because he was caught reading Emerson's essay, "Self-Reliance." ${ }^{47}$ Thoreau had a similar influence, for example, on Tolstoy, who paid to have Thoreau's essay on civil disobedience translated into Russian. In a letter to Eugen Henrich Schmitt, Tolstoy praised Thoreau - whom he called "a very remarkable American author" - as one of the first people to refuse allegiance to the militaristic and slaveholding state by refusing to pay his taxes. Tolstoy praised Thoreau for clearly enunciating the incompatibility of Christian faith and military service "in his beautiful article on the duty of a man not to obey the government, but also in practice showed an example of his disobedience." ${ }^{48}$ Tolstoy was perhaps more profoundly influenced by the Christian nonresistant anarchists, Adin Ballou and William Lloyd Garrison, whom we discussed at the outset. In a letter from 1901, Tolstoy praised Garrison, Emerson, Ballou, and Thoreau - as authors who directly influenced his thinking. ${ }^{49}$ Indeed, the first chapter of Tolstoy's The Kingdom of God is Within You includes an extensive quotation from Garrison's "Declaration" which we quoted above ${ }^{50}$. That chapter also includes and extended discussion of Ballou; and Tolstoy indicates that he was in personal correspondence with Ballou in the last years of Ballou's life.

31 I showed in this article that a line of influence runs from Ballou and the New England anarchists through Emerson, Thoreau, Kropotkin, Tolstoy and an on to William James and Jane Addams. One could outline further connections between anarchism and pragmatism. Peter Manicas has argued that Dewey's democratic ideal is very close to anarchism insofar as it emphasize the importance of local communities, is anti-authoritarian, decentralized, and non-coercive. ${ }^{51}$ It is not surprising to discover, for example, that Dewey was supportive of Emma Goldman and critical of the Sacco and Vanzetti trial. But an exploration of subsequent developments in anarchist thought and in American pragmatism would require another article. 
This paper has provided a brief historical discussion of anarchist trends and influences in the American tradition. This tradition is obviously skeptical about political power. Another common theme is praise for small systems of things and the belief that large systems tend to prevent community, undermine autonomy, and leave us alienated. Anarchists tend to be skeptical of large institutions such as the State. This skepticism is shared by the early Christian anarchists in the American tradition, by Emerson and Thoreau and the Transcendentalists, and by pragmatists such as William James and Jane Addams. The longing for a smaller world in which things make sense is connected to a skeptical and critical approach to political reality, to a pluralistic approach to the world, and to a critique of absolutizing philosophical systems.

So where does this discussion leave us? The fact that individuals no longer feel at home within the waves of mass society and the large systems that govern our lives indicates a reason for skepticism about political life. A similar sort of alienation can be experienced with regard to philosophical systems. Philosophical pragmatism, pluralism, individualism, and anarchism are linked. But the skeptical formulation of these ideas give us reason to be cautious with regard to direct action and social and political movements. American philosophers in the transcendentalist/pragmatist traditions were generally more interested in melioration than in revolution. They were philosophical anarchists, not political revolutionaries. One cannot simply propose to destroy those large-scale systems that produce alienation and anomie. Rather, the solution is to recognize the problem of mediation and alienation within mass society as well as the absolutist and monistic tendencies of metaphysical systems. This recognition points toward a cure: to find ways to reconstruct social and political life -and to approach metaphysical and ethical philosophy - in ways that are more humane and less alienating, more pluralistic and less absolutist. Philosophical anarchism in this tradition is oriented around the hope that somehow the world can be reconstructed in more humane, pluralistic, and democratic ways.

\section{BIBLIOGRAPHY}

ADDAMS J., (1912), Twenty Years at Hull House, New York, MacMillan.

ADDAMS J., (2005), Essays and Speeches on Peace, London, Continuum.

BALlou A., (1839), “Non-Resistance in Relation to Human Government," Boston, Non-Resistance Society, at: [nonresistance.org/docs_pdf/Human_Governments.pdf]

BALlou A., (1846/1910), Christian Nonresistance, Philadelphia, Universal Peace Union.

CAIN W. E. ed., (2000), A Historical Guide to Thoreau, Oxford, Oxford University Press.

Coon D. J., (1996), “'One Moment in the World's Salvation': Anarchism and the Radicalization of William James," The Journal of American History 83 (1), 70-99.

cоткIN G., (1994), William James, Public Philosopher, University of Illinois Press.

European Journal of Pragmatism and American Philosophy, V-2 | 2013 
EMERSON R. W., (1842), “The Senses and the Soul” from Uncollected Prose: Dial Essay 1842 at Ralph Waldo Emerson Texts: [emersoncentral.com/senses_and_the_soul.htm]

EMERSON R. W., (1983), Ralph Waldo Emerson Essays and Lectures, New York, Library of America. FERGUSON K., (2007), William James: Politics in the Pluriverse, Lanham, Rowman and Littlefield. fiala A., (2010), Public War, Private Conscienc, London, Continuum. FIALA A., (2013), Against Religion, Wars, and States: Enlightenment Atheism, Just War Pacifism, and Liberal-Democratic Anarchism, Lanham, Rowman and Littlefield.

GARRISON W. L., (1838), "Declaration of Sentiments Adopted by the Peace Convention (Boston, 1838)," [fair-use.org/the-liberator/1838/09/28/declaration-of-sentiments-adopted-by-the-peaceconvention].

JAMES H. Sr., (1846), What Constitutes the State?, New York, John Allen.

JAMES H. Sr., (1861), The Social Significance of Our Institutions: An Oration Delivered on July 4th, 1861, Boston, Tickner and Fields.

JAMES W., (1981), Pragmatism, Cambridge, Hackett.

JAMEs W., (1900), "What Makes Life Significant" in James W., On Some of Life's Ideals, New York, Henry Holt.

JAMES W., (1992-2004), The Correspondence of William James, Charlottesville, University Press of Virginia.

KENNAN G., (1891), Siberia and the Exile System, London, Osgood.

KROPOTKIN P., (2002), Anarchism: A Collection of Revolutionary Writings, New York, Dover.

MANICAS P., (1982), “John Dewey: Anarchism and the Political State," Transactions of the Peirce Society 18, 2, 133-158.

MANICAS P., (2008), Rescuing Dewey: Essays in Pragmatic Naturalism, Lanham, Rowman and Littlefield.

NIETZSCHE F., (1997), Untimely Meditations, Cambridge, Cambridge University Press.

ROSENWALD L., (2000), in Cain W. E. ed., (2000), A Historical Guide to Thoreau, Oxford, Oxford University Press.

SWIFT M. I., (1918), Can Mankind Survive?, Marshall Jones Co.

SIMmons A. J., (1993), On The Edge of Anarchy: Locke, Consent, and the Limits of Society, Princeton, Princeton University Press, 1993.

SIMMONS A. J., (2009), “Philosophical Anarchism” available at SSRN: http://ssrn.com/ abstract=1344425 or [dx.doi.org/10.2139/ssrn.1344425A].

THOREAU H. D., (2000), Walden and Other Writings, New York, Modern Library.

THOREAU H. D., (2013), Essays: Fully Annotated Edition, New Haven, Yale University Press. Tolstoy L., (1905), The Complete Works of Count Tolstoy: Miscellaneous letters and essays, Estes Publishing.

TOLSToY L., (2013), The Kingdom of God is Within You (from Project Gutenberg ebook: Release Date: July 26, 2013 [EBook \#43302], [gutenberg.org/files/43302/43302-h/43302-h.htm]

WARREN J., (1863), True Civilization, Boston, J. Warren. 
WATNER C., (1980), “Those 'Impossible Citizens': Civil Resistants in 19th Century New England,”

The Journal of Libertarian Studies 3:2, 170-193.

\section{NOTES}

1. James (1981: 116).

2. I explain this in more detail in Fiala (2013).

3. A. John Simmons, "Philosophical Anarchism" (February 16, 2009). Available at SSRN: [ssrn.com/abstract=1344425] or [dx.doi.org/10.2139/ssrn.1344425A]. Also see Simmons (1993).

4. Henry David Thoreau, "Civil Disobedience" in Thoreau (2000: 667).

5. Kropotkin (2002: 299).

6. For John O'Sullivan reference, see Thoreau (2013: 145).

7. W. Lloyd Garrison, "Declaration of Sentiments Adopted by the Peace Convention (Boston, 1838

), [fair-use.org/the-liberator/1838/09/28/declaration-of-sentiments-adopted-by-the-peaceconvention].

8. See discussion in Watner (1979).

9. Lane's March 3, 1843 letter Cain (2000: 155).

10. Warren (1863, no. 62: 28).

11. Ballou (1846/1910), reprinted at [nonresistance.org/docs_pdf/Christian_Nonresistance.pdf]), 9.

12. Ballou (1846/1910: 32).

13. Ballou, "Non-Resistance in Relation to Human Government" (Boston: Non-Resistance Society, 1839-at: [nonresistance.org/docs_pdf/Human_Governments.pdf]?)

14. Ballou (1846/1910: 37).

15. Ballou (ibid.: 89).

16. Ralph Waldo Emerson, "Politics" (Emerson, 1983: 563).

17. Ralph Waldo Emerson, "The Senses and the Soul" from Uncollected Prose: Dial Essay 1842 at Ralph Waldo Emerson Texts ([emersoncentral.com/senses_and_the_soul.htm] - accessed June 18, 2013).

18. Ralph Waldo Emerson, "Montaigne, or The Skeptic" (Emerson, 1983: 694).

19. Emerson (1983: 696).

20. Emerson (ibid.: 702).

21. Ralph Waldo Emerson, "Politics” (Emerson 1983: 567).

22. Ralph Waldo Emerson, "Nominalist and Realist" (Emerson 1983: 583).

23. Ralph Waldo Emerson, "Nominalist and Realist" (Emerson 1983: 587).

24. Ralph Waldo Emerson, "Experience” (Emerson 1983: 473).

25. Ralph Waldo Emerson, "Experience” (Emerson 1983: 481).

26. Thoreau, "Civil Disobedience": 668.

27. Henry James Sr. (1846: 14-15).

28. See, Henry James Sr (1861).

29. James (1992-2004, vol. 9: 362).

30. "What Makes Life Significant" (James, 1900: 57). For discussion, see Ferguson (2007).

31. I discuss James and Roosevelt in Fiala (2010).

32. James (1900: 86).

33. James (1992-2004, vol. 8: 546). Or consider this line from a letter to the pacifist E. H. Crosby (Oct. 1901): "Through small systems kept pure lies the most prominent line of betterment" (ibid., vol. 9: 551).

34. See Thoreau (2000, Chapter 5: "Solitude"). 
35. James (1981: 116).

36. James (ibid.: 117).

37. James (1992-2004, vol. 9: 362). See discussion in Cotkin (1994); also see Coon (1996).

38. James (1981: 16).

39. James (ibid.: 16).

40. Swift (1918: 1).

41. Addams (1912, Chapter 12: "Tolstoyism").

42. Jane Addams, "Count Tolstoy" (1902) in Addams (2005: 25-30).

43. Addams (1912: 407-8).

44. Addams (ibid.: 420).

45. Friedrich Nietzsche (1997, Part Three: "Schopenhauer as Educator": 236).

46. Kropotkin (2002: 299).

47. See Kennan (1891: 326).

48. Leo Tolstoy, "Letter to Eugen Henrich Schmitt" in Tolstoy (1905, vol. 22: 525). For discussion of Tolstoy's reception of Thoreau see Rosenwald in Cain (2000: 153-181).

49. Leo Tolstoy, “A Message to the American People” (1901), in Tolstoy (1905, vol. 23: 462).

50. Leo Tolstoy, The Kingdom of God is Within You (from Project Gutenberg ebook: Release Date: July 26, 2013 [EBook \#43302], http://www.gutenberg.org/files/43302/43302-h/43302-h.htm)

51. Manicas (1982), retrieved in Manicas (2008, Chapter 8).

\section{ABSTRACTS}

This article describes a generally trend in American thought that is skeptical of social and political institutions. This trend can be described as a sort of philosophical anarchism. It develops out of pragmatist and skeptical criticism of absolutism in both philosophical and political systems. This paper traces this theme from its early roots in American Christian anarchism, through transcendentalists such as Emerson and Thoreau, and on to the work of William James and Jane Addams. It also outlines explicit connections between these American philosophers and anarchist authors, such as Tolstoy and Kropotkin.

\section{AUTHOR}

\section{ANDREW FIALA}

California State University, Fresno

afiala[at]csufresno.edu 